\title{
Anna Konert
}

Uczelnia Łazarskiego, Warszawa

a.konert@lazarski.edu.pl

ORCID: https://orcid.org/0000-0002-1188-7087

\section{Zadośćuczynienie za szkodę niemajątkową w wypadkach lotniczych podczas podróży międzynarodowych}

http://dx.doi.org/10.12775.SIT.2021.025

\section{Wprowadzenie}

W przypadku lotów międzynarodowych kwestia odpowiedzialności cywilnej przewoźnika lotniczego za szkody wyrządzone pasażerom uregulowana jest przede wszystkim przez przepisy tzw. systemu warszawsko-montrealskiego, w którego skład wchodzi konwencja warszawska z 1929 r. oraz konwencja montrealska z 1999 r. ${ }^{1}$

Gdy zastosowanie mają wspomniane regulacje ${ }^{2}$, przypisanie odpowiedzialności przewoźnikowi lotniczemu wymaga łącznego spełnienia trzech przesłanek. Po pierwsze, musi powstać szkoda w postaci śmierci lub uszkodzenia ciała pasażera. Po drugie, musi

${ }^{1}$ Konwencja o ujednostajnieniu niektórych prawideł dotyczących międzynarodowego przewozu lotniczego, podpisana w Warszawie 12 października 1929 r.; Konwencja o ujednostajnieniu niektórych prawideł dotyczących międzynarodowego przewozu lotniczego, podpisana w Montrealu 28 maja $1999 \mathrm{r}$.

2 Zob. A. Konert, Odpowiedzialność cywilna przewoźnika lotniczego, Warszawa 2010, s. 76 i n., oraz eadem, Zakres zastosowania Rozporzadzenia 261/2004 - glosa do wyroku TS (czwarta izba) z dnia 10 lipca 2008 r. w sprawie C-173/07 Emirates Airlines Direktion für Deutschland przeciwko Dietherowi Schenkelowi, „Europejski Przegląd Sądowy” 2014, nr 4, s. 37 i n. 
się zdarzyć wypadek, który spowodował szkodę. Po trzecie, wypadek ten musi mieć miejsce na pokładzie statku powietrznego lub $\mathrm{w}$ trakcie jakichkolwiek czynności związanych $\mathrm{z}$ wsiadaniem lub wysiadaniem.

Należy więc ustalić, że miał miejsce wypadek w rozumieniu art. 17 obu konwencji. Musi on stanowić przyczynę śmierci lub uszkodzenia ciała pasażera, a także musi się zdarzyć na pokładzie samolotu lub też w trakcie jakiejkolwiek czynności związanej $\mathrm{z}$ wsiadaniem lub wysiadaniem.

Ustawodawca nie definiuje pojęcia szkody, lecz wspomina jedynie o jej postaciach (szkoda wynikła w razie śmierci lub uszkodzenia ciała pasażera). Powstała więc wątpliwość, czy pasażer ma możliwość dochodzenia zadośćuczynienia za szkody niemajątkowe, zwłaszcza gdy poniósł jedynie szkodę niemajątkową, np. szkodę w postaci lęku przed śmiercią spowodowanego przez silne turbulencje.

W niniejszym opracowaniu przeprowadzono analizę problematyki kompensacji szkód niemajątkowych w świetle przepisów systemu warszawsko-montrealskiego, a także orzeczeń sądów wybranych państw, które ratyfikowały konwencję warszawską i montrealską.

Wykorzystana została metoda analizy formalno-dogmatycznej, najbardziej charakterystyczna dla tekstów prawniczych, oraz metoda prawnoporównawcza, która $z$ kolei okazała się konieczna z uwagi na brak rozwiązań na szczeblu międzynarodowym. Wobec tego niezbędna była analiza przepisów poszczególnych państw oraz orzecznictwa ich sądów. Metoda ta pozwoliła przedstawić różne modele zadośćuczynienia za szkody niemajątkowe.

\section{Definicja „szkody niemajątkowej” w świetle przepisów systemu warszawsko- -montrealskiego}

Od momentu uchwalenia konwencji warszawskiej powstała wątpliwość, czy istnieje możliwość uzyskania zadośćuczynienia za krzywdy moralne (cierpienia psychiczne, emocjonalny rozstrój zdrowia itp.), zwłaszcza że pojęcie szkód niemajątkowych i ich 
naprawienia było różnorodnie rozumiane na tle poszczególnych systemów prawnych ${ }^{3}$.

Konwencja warszawska, w oryginalnym brzmieniu (w języku francuskim) zawiera zwroty mort, blessure ou toute autre lésion corporelle, czyli śmierć, zranienie lub wszelkiego innego rodzaju uszkodzenia ciała, co zostało przetłumaczone na angielski jako death or wounding or any other bodily injury. Zwrot lésion corporelle, $\mathrm{w}$ przeciwieństwie do mort i blessure, od początku budził wątpliwości. W nieoficjalnym tłumaczeniu konwencji warszawskiej, zarówno podczas debaty nad jej ratyfikacją w Stanach Zjednoczonych, jak i w Wielkiej Brytanii (Carriage by Air Acts, Order 1967), zwrot lésion corporelle został ujęty jako bodily injury. W kolejnych aktach prawnych, które zmieniały lub uzupełniały konwencję warszawską, znalazł się natomiast zwrot personal injury, podczas gdy wersja francuska zawierała niezmienione pojęcie lésion corporelle $e^{4}$ Pod względem gramatycznym termin bodily injury jest bez wątpienia najodpowiedniejszym tłumaczeniem lésion corporelle, lecz jego znaczeniu w języku francuskim, a także w innych systemach prawnych bardziej odpowiada termin personal injury ${ }^{5}$. W związku $z$ tym nie było jasności, czy w świetle przepisów konwencji warszawskiej istnieje możliwość uzyskania odszkodowania za krzywdy moralne ${ }^{6}$.

Konwencja montrealska (w kilku oryginalnych brzmieniach) nie zawiera już pojęcia blessure, a jedynie: w języku francuskim - mort ou lésion corporelle, w języku angielskim - death or bodily injury. Oficjalne polskie tłumaczenie konwencji zawiera zwrot „śmierć, uszkodzenie ciała lub rozstrój zdrowia”, mimo że wskazuje on na szerszy zakres szkód. Takie rozszerzenie podyktowane jest brakiem konstrukcji odpowiadającej ujęciu „konwencyjnej szkody”, która przecież nie została zdefiniowana. Najbliższy pojęciu lésion corporelle wydaje się zwrot „uszkodzenie ciała i rozstrój zdrowia”, który

${ }^{3}$ Zob. U. von Jeinsen, A. Konert, Are non pecuniary damages recoverable in Europe? A Comparative Analysis, „Annals of Air and Space Law” 2009, Vol. 24.

4 Protokół haski, protokół gwatemalski czy też Porozumienie montrealskie z 1966 r.

5 A. Konert, Odpowiedzialność cywilna, s. 97.

6 Ibidem. 
znajduje się także w art. $444 \S 1$ polskiego Kodeksu cywilnego ${ }^{7}$. Pozostawienie $\mathrm{w}$ konwencji montrealskiej zwrotu bodily injury i rezygnacja $z$ wprowadzenia zwrotu mental injury mogą prowadzić do dwóch stwierdzeń: iż nie ma możliwości uzyskania zadośćuczynienia za same krzywdy moralne w świetle przepisów konwencji montrealskiej albo że krzywdy moralne są włączone w pojęcie bodily injury, biorąc pod uwagę ich związek $z$ uszkodzeniem ciała ${ }^{8}$.

\section{Zadośćuczynienie za szkodę niemajątkową w orzecznictwie amerykańskim}

Pierwsze roszczenia o zadośćuczynienie za krzywdy moralne zostały wniesione na podstawie przepisów konwencji dopiero w $1970 \mathrm{r}$. Pasażerowie, którzy nie doznali żadnych obrażeń fizycznych, twierdzili, że doświadczyli cierpienia psychicznego z powodu ataków terrorystycznych ${ }^{9}$. Przedstawione poniżej trzy wyroki ilustrują różne poglądy i podejścia prezentowane przez sądy amerykańskie. Choć stan faktyczny we wszystkich sprawach był identyczny, sądy przyjęły inną argumentację. W dniu 6 września 1970 r. terroryści z Ludowego Frontu Wyzwolenia Palestyny porwali amerykański samolot Boeing 707 linii Trans World Airlines lecący $z$ Frankfurtu do Nowego Jorku ze 141 pasażerami na pokładzie. Piloci zostali zmuszeni do lądowania na pustyni w Jordanii. W okresie „pustynnej niewoli” powodowie doświadczyli poważnego szoku emocjonalnego, obawiając się, że ich życie może być w niebezpieczeństwie. Byli uwięzieni na pokładzie samolotu przez sześć dni, bez klimatyzacji $\mathrm{w}$ wysokich temperaturach, pozbawieni regularnych posiłków.

W sprawie Burnett $v$. TWA ${ }^{10}$ sąd federalny w Nowym Meksyku zauważył, że prawo francuskie wyraźnie odróżnia uszkodzenia ciała

7 Ibidem, s. 106.

8 Ibidem, s. 104 i n.

9 R.J. Rivers jr, Torts - International infliction of emotional distress, „Suffolk Transnational Law Journal” 1990, No. 14, s. 357; Ch. Thalin, The Air Carrier's Liability for Passenger Damages - Article 17 of the Warsaw System and the new Montreal Convention, Master thesis 2002, s. 39.

10 Burnett $v$. TWA, 368 F Supp 1152 (D.Ct. 1973). 
(lésion corporelle) od urazu psychicznego (lésion mental) i że te dwa pojęcia wzajemnie się wykluczają. Wobec tego cierpienie psychiczne nie wchodzi w zakres pojęcia szkody w art. 17.

Natomiast w sprawie Rosman v. TWA ${ }^{11}$ nowojorski Sąd Apelacyjny skupił się na tłumaczeniu na język angielski pojęcia szkody $z$ art. 17 i uznał, że zadośćuczynienie można zasądzić jedynie w przypadku wyrządzenia krzywdy moralnej, która wynika $z$ fizycznego uszkodzenia ciała (flown from) ${ }^{12}$.

Sąd federalny w Nowym Jorku w wyroku wydanym w sprawie Husserl v. Swiss Air Transport Co. ${ }^{13}$ wskazał na intencje autorów i sygnatariuszy konwencji i stwierdził, że nie zamierzali oni wykluczyć dochodzenia roszczeń z tytułu szkód niemajątkowych, a więc urazy czysto niemajątkowe mogą być przedmiotem roszczenia.

Precedensowe orzeczenie, dotyczące zadośćuczynienia w systemie warszawskim, zapadło w sprawie Eastern Airlines v. Floyd. Wyrok został wydany w następującym stanie faktycznym. W dniu 5 maja 1983 r., podczas lotu Eastern Airlines z Miami na Bahamy, tuż po starcie, w jednym $z$ silników spadło ciśnienie oleju. Wkrótce potem drugi i trzeci silnik przestały działać. Samolot zaczął tracić wysokość, a pasażerowie zostali poinformowani o tym, że będzie lądowanie awaryjne na Oceanie Atlantyckim. Na szczęście załoga zdołała ponownie uruchomić silnik i wylądować bezpiecznie na lotnisku w Miami. Pasażerowie dochodzili zadośćuczynienia za cierpienia psychiczne. Sąd Najwyższy uznał, że w świetle art. 17 konwencji warszawskiej nie ma możliwości dochodzenia zadośćuczynienia za szkody niemajątkowe, którym nie towarzyszy śmierć lub fizyczne uszkodzenie ciała (death, physical injury, or

11 1974, N.Y.A.Ct., 34 N.Y.3d 385, 314 N.E.2d 848, 358 N.Y.S. 2 d 97.

12 "Thus, as we read article 17, the compensable injures must e 'bodily' but there may be intermediate causal link which is 'mental' between the cause - the 'accident' - and the effect - the 'bodily injury'. And once that predicate of liability - the 'bodily injury' - is established, then the damages sustained as a result of the 'bodily injury' are compensable including mental suffering. However, only the damages flowing from the 'bodily injury', whatever the causal link, are compensable", ibidem.

13351 F. Supp. 702, S.D.N.Y. 1972. 
physical manifestation of injury ${ }^{14}$. Nie chodzi tu o sytuację, w której wystarczy jakiekolwiek uszkodzenie fizyczne ciała, by pasażer mógł otrzymać zadośćuczynienie za szkodę niemajątkową. Kompensacji może bowiem podlegać wyłącznie szkoda niemajątkowa, która bezpośrednio dotyczy, „wypływa” (flows from) z konkretnego uszkodzenia ciała. Przykładowo w wypadku lotniczym American Airlines w Little Rock młoda kobieta, która przeżyła katastrofę, lecz jej noga została przebita i zgnieciona przez śruby $z$ samolotu, doznała traumatycznego zapalenia ścięgna mięśnia czworogłowego, a także szkody spowodowanej wdychaniem dymu. Został u niej również zdiagnozowany zespół stresu pourazowego (tzw. PTSD). Sąd I instancji przyznał jej odszkodowanie w wysokości $6,5 \mathrm{mln}$ dolarów, lecz Sąd Najwyższy stwierdził, że szkody niemajątkowe muszą bezpośrednio wynikać $z$ urazów fizycznych spowodowanych wypadkiem. Ponadto w ocenie sądu powód może uzyskać odszkodowanie tylko za szkody, które wynikają z urazów nóg oraz stanowią konsekwencję wdychania dymu, nie obejmują więc zespołu stresu pourazowego ${ }^{15}$. Na takim samym stanowisku stanęły sądy w wielu innych sprawach ${ }^{16}$. Bezsprzeczne wydaje się zatem stwierdzenie, że

14 1991, S.Ct. 499 U.S. 530, 111 S.Ct. 1489. Zob. J.P. Boulee, Recovery for mental injuries that are accompanied by physical injuries under article 17 of the Warsaw Convention: the progeny of Eastern airlines, inc. V. Floyd, „Georgia Journal of International and Comparative Law" 1994, Vol. 24; M.J. Holland, The Puzzle of Defining “Bodily Injury” under the Warsaw Convention, „Defense Counsel Journal” 2003, Vol. 70.

15 Zob. L.M. Fromm, Eastern airlines v. Floyd: Airline passengers denied recovery for emotional distress under the Warsaw Convention, „Akron Law Review” 1991, Vol. 25; J.P. Boulee, op.cit., s. 501, 505.

16 Alvarez v. American Airlines, 1999 WL 691922 (S.D.N.Y. Sept. 7, 1999); Jack $v$. Trans World Airlines, Inc. (N.D. Cal. 1994); In re Inflight Explosion on Trans World Airlines, 778 F. Supp. 625, E.D.N.Y. 1991; Lloyd v. American Airlines, 291 F.3d 503 ( $8^{\text {th }}$ Cir. 2002); Beck v. KLM, 14 Avi. 18.210, 1977; In re Air Crash at Little Rock, Arkansas, 291 F.3d. 503 ( $2^{\text {nd }}$ Cir. 2002); Erhlich v. American Airlines, 2002 U.D. Dis. Lexis 21419 (E.D.N.Y. 2002); Searcy v. American Airlines, 2002 U.S. Dist. Lexis 9648 (E.D.La. 2002); American Airlines v. Georgeopoulos \& Anor, N.S.W.Ct.App. Aug. 4, 1998; Re in Crash at Taipei, Taiwan, 30 Avi. Cas (CHH) 15.509 (C.D. Cal. 2004); Potgieter v. British Airways, 2005 C.P.D., High Ct. of South Africa, Jan. 25, 2005; Ikekpeazu v. Air France, 2004 WL 2810063 (D.Conn. Dec. 6, 2004). 
pasażer może dochodzić zadośćuczynienia za szkody niemajątkowe, gdy wynikły one $z$ fizycznych uszkodzeń ciała lub zostały przez nie spowodowane ${ }^{17}$. W świetle przepisów konwencji warszawskiej zasadą jest więc brak możliwości dochodzenia zadośćuczynienia za same szkody niemajątkowe, chyba że wynikają one bezpośrednio ze szkody fizycznej (ang. flow from/cause by).

Na konferencji montrealskiej delegacje Norwegii i Szwecji zaproponowały wprowadzenie do nowej konwencji pojęcia mental injury, twierdząc, że bodily injury odnosi się tylko do fizycznego uszkodzenia ciała. Proponowano wprowadzenie oddzielnego typu odszkodowania za mental injury, biorąc pod uwagę szkody na zdrowiu poszkodowanego. Wyróżniono więc trzy rodzaje szkód: uszkodzenie ciała (ang. bodily injury), krzywdy moralne związane ze szkodą fizyczną (ang. mental injury associated with bodily injury) oraz krzywdy moralne mające negatywny wpływ na zdrowie pasażera (ang. mental injury which has a significant adverse effect on the health of the passenger) ${ }^{18}$.

Ostatecznie jednak nie zdecydowano się na wprowadzenie zwrotu mental injury. Analizując całokształt dyskusji podczas konferencji, można dojść do wniosku, że żadne $z$ państw nie negowało samej możliwości dochodzenia zadośćuczynienia za krzywdy moralne. Zatem błędne byłoby twierdzenie, że w świetle konwencji można dochodzić tylko odszkodowania za szkody majątkowe ${ }^{19}$.

Analiza orzecznictwa sądów amerykańskich na tle konwencji montrealskiej prowadzi do stwierdzenia, że uzyskanie zadośćuczynienia za krzywdy moralne jest możliwe (tak jak w systemie

17 Zob. także J. Rees, Getting from Warsaw to Gerona: a tour operator's liability, „International Travel Law Journal” 2004, Vol. 1, s. 7 i n., który analizuje wyrok sądu w sprawie Akehurst \& Others $v$. Thomson Holidays Ltd. and Britannia Airways Ltd., w którym sąd nakazał organizatorowi wycieczki wypłatę zadośćuczynienia za szkody moralne.

18 International Conference of Air Law, Montreal, 10-28 May 1999, Min. of the $3^{\text {rd }}$ Meeting, s. 67-74.

19 Zob. P.S. Dempsey, Accidents \& Injuries in International Air Law: The Clash of the Titans, „Annals of Air and Space Law” 2009, Vol. 34, s. 285-310, przedruk w: „Korean Journal of International Law” 2009, s. 235-270. 
warszawskim) jedynie wówczas, gdy szkoda niemajątkowa jest spowodowana fizycznym uszkodzeniem ciała ${ }^{20}$.

\section{Zadośćuczynienie za szkodę niemajątkową w orzecznictwie wybranych państw}

\subsection{Nieuznanie roszczenia o zadośćuczynienie za szkodę niemajątkową}

W dniu 28 maja 1992 r. samolot Singapore Airlines startował z Aten do Sydney przez Singapur. Wkrótce po starcie pasażer Kotsambasis zobaczył dym w prawym silniku, który zaczął się palić. Załoga poinformowała pasażerów, że wystąpił błąd w pracy silnika i że samolot wróci do Aten, ale najpierw musi pozbyć się paliwa. Samolot wylądował dopiero godzinę po starcie, a pasażerom uniemożliwiono wysiadanie $z$ samolotu przez kolejne 2,5 godziny. Pasażer Kotsambasis złożył pozew przeciwko Singapore Airlines, żądając zadośćuczynienia. Sąd Apelacyjny Nowej Południowej Walii orzekł, że pojęcia bodily injury oraz lésion corporelle właściwie są tożsame i nie ma jasności co do tego, czy odnoszą się do urazów psychicznych. Odwołał się do zasad interpretacji umów międzynarodowych $z$ art. 31 i 32 Konwencji wiedeńskiej o prawie traktatów ${ }^{21}$ i doszedł do wniosku, że dwuznaczność można rozwiązać, patrząc na intencję stron umowy i przyjmując celowe podejście do interpre-

${ }^{20}$ Kruger v. United Airlines, 481 F. Supp. 2d 1005; 2007 U.S. Dist. Lexis 14747 („Punitive damages were not available under the Montreal Convention, and emotional distress damages were limited to recovery for emotional distress flowing from physical injuries"); Sheila Booker v. BWIA West Indies Airways Limited, U.S. Dist. Court for the Eastern Dist. of New York, May 8, 2007, 06CV-2146 (RER), 2007 U.S. Dist. Lexis 33660. Zob. J.J. Immel, The Montreal Convention and Recovery for Free-Standing Emotional Distress under Article 17, „Issues in Aviation Law and Policy” 2013, Vol. 13, No. 1, s. 75 i n.; P.S. Dempsey, op.cit.

${ }^{21}$ Konwencja wiedeńska o prawie traktatów, KWPT - konwencja uchwalona w Wiedniu 22 maja 1969 r., a otwarta do podpisu 23 maja 1969 r. (Dz.U. z 1990 r. Nr 74, poz. 439). 
tacji konwencji. Według sądu termin bodily injury nie odnosi się do purely psychological injury ${ }^{22}$.

Sąd Najwyższy Estonii w orzeczeniu z 26 maja 2005 r. ${ }^{23}$ podkreślił, że odszkodowanie nie może być przyznane tylko za „cierpienia psychiczne i chwilową utratę poczucia własnej wartości”. Według sądu powstanie każdej szkody musi być odpowiednio udowodnione. Celem tego orzeczenia było powstrzymanie sądów przed przyznawaniem zadośćuczynienia za krzywdy moralne bez posiadania odpowiednich dowodów na ich rzeczywiste zaistnienie oraz bez „ważenia wszystkich argumentów przedstawionych przez strony" ${ }^{24}$. Niemniej jednak sąd nie stwierdził tu jednoznacznie, że nie ma w ogóle takiej możliwości, a jedynie położył nacisk na związek przyczynowy.

Rozwiązania zaproponowane przez sądy w powyższych sprawach zasługują na aprobatę. Wprowadziły one bowiem zasadę, że nie ma możliwości uzyskania wyłącznie zadośćuczynienia za krzywdy moralne. Należy jednak postawić tezę, że sądy te nie wykluczają możliwości uzyskania zadośćuczynienia w pewnych sytuacjach. Nacisk został bowiem położony na odpowiednie udowodnienie powstałej szkody, w tym wnikliwą analizę stanu zdrowia pasażera.

\subsection{Uznanie roszczenia o zadośćuczynienie za szkodę niemajątkową}

Izraelski Sąd Najwyższy w wyroku w sprawie Daddon v. Air France ${ }^{25}$ uznał, że cierpienia psychiczne doznane przez pasażerów na skutek porwania samolotu przez terrorystów mieszczą się w zakresie pojęcia bodily injury $z$ art. 17 konwencji. Sąd powoływał się na prawo krajowe, według którego taka możliwość istnieje.

22 Kotsambasis v. Singapore Airlines, 148 ALR 498 (42 NSWLR 110).

23 Riigikohus (Supreme Court), 26 May 2005, No. 3-2-1-34-05. (2005) RT III, 20, 207, za: I. Kull, w: European Tort Law 2005, eds. H. Koziol, B.C. Steininger, Wien-New York 2006, s. 254-255.

24 Ibidem.

25 (1984) 1 S \& B Av R V11/141. 
W brytyjskiej Izbie Lordów lord Steyn orzekł w sprawie Morris v. $K L M^{26}$, że cierpienie psychiczne spowodowane przez fizyczne uszkodzenie ciała podlega kompensacji. W analizowanej sprawie 15-letnia dziewczynka cierpiała na depresję po molestowaniu jej przez innego pasażera na pokładzie lotu z Kuala Lumpur do Amsterdamu. Lord Nicholls stwierdził, że wyrażenia bodily injury czy lésion corporelle dotyczą szkody cielesnej. Jednak zauważył, że mózg też jest częścią ciała, a czasami może ulec kontuzji. Jego zdaniem nauka medyczna awansowała do poziomu, który może wskazywać na uszkodzenia w mózgu powodujące depresję kliniczną, a jeśli tak, to takie uszkodzenia mogą być przedmiotem roszczenia odszkodowawczego.

Sprawa King $v$. Bristow Hellicopters ${ }^{27}$ dotyczyła startu helikoptera $\mathrm{z}$ pływającej platformy na Morzu Północnym podczas złych warunków pogodowych. $Z$ powodu awarii silnika na pokładzie pojawił się dym , a pasażerowie obawiali się, że śmigłowiec rozbije się w morzu. Ostatecznie pilotowi udało się wylądować na platformie i pasażerowie bezpiecznie wysiedli. Pasażer King, na skutek psychicznej traumy, doznał choroby wrzodowej. Brytyjska Izba Lordów uznała, że pasażerowi należy się odszkodowanie.

W Polsce, w wyroku z dnia 24 stycznia 2014 r., Sąd Apelacyjny w Warszawie ${ }^{28}$ nie podzielił stanowiska sądu I instancji, według którego art. 17 konwencji montrealskiej, stanowiący, że przewoźnik ponosi odpowiedzialność za szkodę wynikłą w razie smierci albo uszkodzenia ciała lub rozstroju zdrowia pasażera, dotyczy wyłącznie szkody o charakterze materialnym. Sąd przyjął, że nie ma podstaw do tego, aby pojęcie szkody użyte w art. 17 zawężać do szkody materialnej. Dla polskich pasażerów oznacza to, że mają możliwość uzyskania zadośćuczynienia za krzywdy moralne doznane wskutek wypadku lotniczego. Powstaje jednak pytanie, czy pasażerowie również mieliby taką możliwość w razie doznania tylko szkody niemajątkowej bez uszkodzenia ciała. Sąd w omawianej sprawie nie odniósł się do tego zagadnienia. Wydaje

26 [2002] UKHL 7, [2002] 2 AC 628 (U.K. House of Lords 2002).

27 [2002] UKHL 7, [2002] 2 AC 628 (U.K. House of Lords 2002).

28 I ACa 1187/13, Lex nr 1480608. 
się jednak, że tę kwestię należy oceniać z punktu widzenia przepisów polskiego Kodeksu cywilnego. W razie więc braku uszkodzenia ciała lub wywołania rozstroju zdrowia pasażera nie ma możliwości uzyskania zadośćuczynienia na podstawie art. 445 k.c. Jeśli jednak poszkodowany (pasażer) udowodni, że zostało naruszone jego dobro osobiste, sąd będzie mógł przyznać odpowiednią sumę tytułem zadośćuczynienia za doznaną krzywdę na podstawie art. 448 k.c. Z uwagi na otwarty katalog dóbr osobistych teoretycznie taka możliwość istnieje. W praktyce jednak trudno wyobrazić sobie sytuację, w której wskutek wypadku lotniczego zostaje naruszone dobro osobiste inne niż zdrowie i życie. Można natomiast wyobrazić sobie sytuację, w której wskutek silnego wstrząsu psychicznego wywołanego uzasadnionym lękiem przed śmiercią (wskutek silnych turbulencji i awaryjnego lądowania w płonącym samolocie) pasażer doznał awiofobii lub tzw. zespołu stresu pourazowego (Post Traumatic Stress Disorder - PTSD). PTSD obejmuje zaburzenia psychofizyczne będące efektem przeżycia traumatycznego wydarzenia (np. bombardowanie, tortury, terroryzm, tzw. men-made disorders $^{29}$ ). Pojęcie to zostało oficjalnie wprowadzone do słownictwa profesjonalnego służby zdrowia w 1980 r. przez Amerykańskie Towarzystwo Psychiatryczne ${ }^{30}$. Kryteria rozpoznania PTSD zostały

29 P. Krukow, A. Lipczyński, Zespół stresu pourazowego - charakterystyka psychologiczna i neuropsychologiczna, Psychiatria.pl, 21 lipca 2007 r., https:// www.psychiatria.pl/artykul/zespol-stresu-pourazowego-charakterystyka-psychologiczna-i-neuropsychologiczna/3694/3 (dostęp: 15.09.2021 r.). „Dotyczy ono permanentnego odtwarzania traumy, a w konsekwencji koszmarnych snów związanych $z$ traumą, przypominania i rozpamiętywania jej, uporczywego unikania - przede wszystkim wspomnień i sytuacji kojarzących się z traumatycznym wydarzeniem i zmniejszeniem ogólnej reaktywności - unikania uczuć, myśli związanych z traumą, przypominania ważnych aspektów traumy, chłodu emocjonalnego w kontaktach interpersonalnych. Dotkliwymi objawami psychofizycznego pobudzenia są zaburzenia z zasypianiem lub snem, trudności w koncentracji, drażliwość, wybuchy gniewu i złości. Często powtarzającym się objawem występującym w PTSD jest silne napięcie wywołane każdym wspomnieniem o wydarzeniu, czy też przedmiotem, który się z tym wydarzeniem kojarzy, a także przeżywania nagłego poczucia o intruzywnym charakterze, że wydarzenie znów ma miejsce”.

${ }^{30}$ American Psychiatric Association, Diagnostic and Statistical Manual of Mental Disorders, $3^{\text {rd }}$ edition, Washington DC, APA 1980. 
uregulowane w tzw. DSM-IV, czyli systemie diagnozy nozologicznej Amerykańskiego Towarzystwa Psychiatrycznego (Diagnostic and Statistical Manual of Mental Disorders) ${ }^{31}$. Sądy napotkały trudności w ustaleniu, czy PTSD należy traktować jako emotional injury, czy też jako bodily injury. PTSD stanowi coś pomiędzy i jest szkodą, którą zdecydowana większość sądów traktuje jako szkodę w rozumieniu art. 17 konwencji, przyznając odszkodowanie ${ }^{32}$.

Trybunał Sprawiedliwości UE również wyraził swoje stanowisko (na które zresztą powołuje się polski sąd). W wyroku z dnia 6 maja 2010 r. w sprawie C-63/09 (Axel Walz v. Clickair SA) TSUE orzekł, że pojęcie szkody, o którym mowa w rozdziale III konwencji, należy rozumieć jako obejmujące zarówno szkodę o charakterze materialnym, jak i krzywdę. Stanowisko to potwierdzone zostało w wyroku Trybunału z dnia 13 października 2011 r. w sprawie C-83/10 (Sousa Rodríguez $i$ in.). Wprawdzie Trybunał nie wypowiedział się bezpośrednio, czy można uzyskać tylko zadośćuczynienie za szkodę niemajątkową, niemniej należy uznać, że taka była jego wola. Po pierwsze, orzeczenia Trybunału dotyczące praw pasażerów lotniczych oraz odpowiedzialności przewoźnika lotniczego charakteryzują się prokonsumenckim podejściem. Trybunał dokonuje bowiem nie tylko interpretacji rozszerzającej przepisów niebudzących wątpliwości (w tym zwłaszcza przepisów rozporządzenia $261 / 2204^{33}$ ), ale wręcz można mówić o prawotwórczej mocy

31 M.M. Kirpalani, Ch. Hasiotis, Defense of Psychological Injury Claims: An Update on Post-Traumatic Stress Disorder, „Journal of Air Law \& Commerce”, SMU, 1996, Vol. 62.

32 Terrafranca $v$. Virgin Atl. Airways, Ltd., 151 F.3d 108, 109 (3 ${ }^{\text {rd }}$ Cir. 1998); Alvarez v. American Airlines, Inc.No. 98-Civ.-1027, 1999 WL 691922 (S.D.N.Y. Sept. 7, 1999); Turturro v. Continental Airlines, 128 F. Supp. 2d 170, 174 (S.D.N.Y. 2001); Ligeti v. British Airways, No. 00-Civ.-2936(FM), 2001 WL 1356238, at 1 (S.D.N.Y. Nov. 5, 2001); In re Air Crash at Little Rock Arkansas, 291 F.3d 503, 506 (8 $8^{\text {th }}$ Cir. 2002); Bobian v. CSA Czech Airlines, 93 Fed. Appx. 406, 407 ( $3^{\text {rd }}$ Cir. 2004), Casey v. Pel-Air Aviation Pty Ltd.; Helm v. Pel-Air Aviation Pty Ltd. [2015] NSWSC 566. Zob. szeroko na ten temat: P.S. Dempsey, op.cit., oraz J. Schmidt, Compensability for PTSD under the Montreal Convention: Psychiatric Injury as a Bodily Injury, „Journal Psychiatry, Psychology and Law" 2015, Vol. 22, Issue 5.

33 Rozporządzenie (WE) nr 261/2004 z dnia 11 lutego 2004 r. ustanawiające wspólne zasady odszkodowania i pomocy dla pasażerów w przypadku 
orzeczeń Trybunału ${ }^{34}$. Po drugie, skoro Trybunał w wyroku w sprawie Axel Walz v. Clickair SA uznał, że istnieje możliwość uzyskania zadośćuczynienia za zgubiony bagaż (a takiej możliwości nie ma w świetle przepisów konwencji warszawskiej i montrealskiej) ${ }^{35}$, to tym bardziej należałoby wnioskować, iż przyznałby zadośćuczynienie za szkodę niemajątkową (szkodę na osobie).

\section{Rozważania szczegółowe na temat zadośćuczynienia za lęk przed śmiercią}

Interpretacja przepisów konwencji polegająca na uznaniu, że tylko szkody majątkowe podlegają kompensacji, może prowadzić do nielogicznych wniosków. Można sobie wyobrazić dwie sytuacje. W pierwszej, z powodu awarii silnika, samolot nagle zaczyna spadać. Tuż przed zderzeniem piloci jednak są w stanie ponownie uruchomić silnik i samolot bezpiecznie ląduje. W drugiej sytuacji natomiast nie udaje się pilotom ponownie uruchomić silnika i wszyscy pasażerowie giną. W pierwszej sytuacji pasażerowie, którzy przeżyli, występują $z$ roszczeniem o zadośćuczynienie za lęk przed śmiercią (pre-death fright). Pasażerowie byli bowiem przekonani, że zginą. W drugiej sytuacji rodziny zmarłych występują z roszczeniem o zadośćuczynienie za lęk przed śmiercią oraz ból i cierpienie, jakie przeżyli pasażerowie, wiedząc, że umrą. Według powyższej interpretacji przepisów konwencji pasażerowie w pierwszej sytuacji nie uzyskają zadośćuczynienia, w drugiej zaś - tak (jeśli pozwala na to prawo krajowe). Pojawia się zatem pytanie, czy wobec tego uzasadniona obawa przed śmiercią podczas katastrofy lotniczej może

odmowy przyjęcia na pokład albo odwołania lub dużego opóźnienia lotów (Dz.Urz. UE L 2004, Nr 46, s. 1).

${ }^{34}$ Zob. A. Konert, Prawotwórcza moc TSUE - clara non sunt interpretanda?, w: Internacjonalizacja i europeizacja prawa lotniczego. Księga pamiątkowa na cześć Prof. dr. hab. Marka Żylicza, red. A. Konert, Warszawa 2015. Zob. też A. Konert, Zadośćuczynienie za szkodę niemajątkowa spowodowana utrata bagażu - glosa do wyroku TS (trzecia izba) z 6.05.2010 r. w sprawie C-63/09 Axel Walz v. Clickair S.A., „Europejski Przegląd Sądowy” 2011, nr 10.

35 Zob. szerzej: A. Konert, Odpowiedzialność cywilna, s. 174. 
być przedmiotem roszczenia tylko wtedy, gdy pasażer faktycznie umiera. Jeśli pasażer jest przekonany, że umrze, i cierpi przez 10 minut, lecz przeżyje, to nie uzyska zadośćuczynienia, ale jeśli tak samo cierpi przez 10 sekund i ostatecznie zginie, to jego bliskim należy się zadośćuczynienie za jego cierpienie ${ }^{36}$. Jeżeli stewardesa wyleje wrzątek na małe dziecko, które dozna poparzenia i któremu pozostaną blizny do końca życia, to dziecko będzie mogło uzyskać zadośćuczynienie, ale jego matka siedząca obok, obserwująca całe wydarzenie, już nie ${ }^{37}$.

Obie konwencje nie określają definicji szkody ani szczegółowych zasad odpowiedzialności. Wobec tego kwestie te zostały pozostawione sądom krajowym ${ }^{38}$. Takie upoważnienie zawarte jest w art. 24 konwencji warszawskiej oraz w art. 29 konwencji montrealskiej, który stanowi, że w przewozie osób, bagażu i ładunku jakiekolwiek powództwo dla uzyskania odszkodowania, jakkolwiek uzasadnione, zarówno na podstawie niniejszej konwencji, jak i z umowy lub deliktu, może zostać wytoczone wyłącznie $z$ zastrzeżeniem warunków i takich granic odpowiedzialności, jak te określone w niniejszej konwencji, bez uszczerbku dla tego, kim są osoby mające prawo wniesienia pozwu.

Interesujące rozwiązanie przewiduje prawo lotnicze we Włoszech. Włoski kodeks lotniczy (art. 941) stanowi bowiem, że odpowiedzialność przewoźnika za szkody na osobie pasażera (użyto terminu personal injury zamiast bodily injury) regulowana jest przez prawo UE oraz przepisy konwencji montrealskiej, które stosowane są jako prawo krajowe. Wobec tego, jeśli zastosowanie ma prawo włoskie, przewoźnik lotniczy będzie ponosił odpowiedzialność za personal injury zgodnie $z$ zasadami wynikającymi $z$ włoskiej konstytucji. W większości krajów dochodzi jednak do konfrontacji przepisów konwencji międzynarodowych (warszawskiej i montrealskiej) oraz

36 W wypadku lotniczym Trans World Airlines, w którym bomba eksplodowała pod siedzeniem pasażera, który był świadomy, co się $z$ nim dzieje przez 10 sekund, jego rodzina otrzymała zadośćuczynienie za 10-sekundowe cierpienie pasażera (778 F.Supp. 625, 626-27, EDNY1991).

37 Fishman v. Delta Airlines, 132 F. $3^{\text {rd }} 138$ ( $2^{\text {nd }}$ Cir. 1998).

38 Zicherman v. Korean Air Lines Co., 516 U.S. 217, 225 (1996). 
przepisów krajowych. Niektóre ustawodawstwa powołują się na bogate orzecznictwo sądów amerykańskich, wskazując na możliwość uzyskania zadośćuczynienia pod warunkiem, że szkoda niemajątkowa powstała na skutek fizycznego uszkodzenia ciała. Inne $z$ kolei pozostawiają tę kwestię całkowicie sądom krajowym.

Pojawia się pytanie, czy rodziny zmarłych mogą otrzymać zadośćuczynienie za ich własne cierpienie, czy jedynie za ból i cierpienie najbliższych.

W dniu 24 marca 2015 r. o godzinie 10.53 w południowo-wschodniej części Francji rozbił się o ziemię samolot linii Germanwings lecący z Barcelony do Düsseldorfu. Drugi pilot, gdy został sam w kabinie, świadomie odmówił otwarcia drzwi i w ostatniej fazie lotu manualnie wielokrotnie zmieniał ustawienia parametrów zniżania, nie odpowiadając na wezwania kontroli lotów. Uruchomił opadanie maszyny lecącej na autopilocie i doprowadził do katastrofy, w której zginęło 150 osób. Rodziny zmarłych otrzymały, zgodnie z przepisami konwencji montrealskiej z 1999 r., zaliczki w wysokości 50000 euro. Przewoźnik zaproponował ponadto wypłatę 25000 euro zadośćuczynienia dla każdego poszkodowanego. Oferta ta została jednak odrzucona przez poszkodowanych. Jak wysokie będą odszkodowania, będzie zależało od tego, gdzie zostały złożone pozwy. Może mieć tu zastosowanie prawo niemieckie, gdyż przewoźnik ma siedzibę $\mathrm{w}$ Niemczech, a miejscem przeznaczenia dla wielu pasażerów były właśnie Niemcy. Ponadto wielu pasażerów miało główne i stałe miejsce zamieszkania w Niemczech w chwili wypad$\mathrm{ku}^{39}$. Według prawa niemieckiego utrata bliskiej osoby w wypadku nie uzasadnia automatycznie roszczenia o naprawienie krzywdy moralnej. Tylko w pewnych, dość surowych warunkach najbliżsi krewni zmarłego mogą być uprawnieni do otrzymania zadośćuczynienia (w ramach odpowiedzialności deliktowej) $z$ tytułu tzw. szoku nerwowego (Schockschaden). Zadośćuczynienie za Schockschaden jest przyznawane przez niemieckie sądy jedynie w przypadku spełnienia pewnych warunków. Po pierwsze, poszkodowany musi być najbliższym krewnym zmarłego (obok członków rodziny także narzeczony lub partner). Po drugie, u poszkodowanego muszą

39 Zob. art. 33 konwencji montrealskiej z 1999 r. 
wystąpić poważne zaburzenia psychiczne $z$ powodu śmierci osoby bliskiej. Musi on wykazać nadzwyczajny rozstrój zdrowia, który różni się od takiego, jaki dotyka zwykle osoby cierpiące $z$ powodu śmierci osoby najbliższej. Wreszcie, zdarzenie powodujące szkodę (śmierć osoby bliskiej) musi obiektywnie być wystarczającym powodem do wystąpienia szkody w postaci cierpienia psychicznego członka rodziny. Według orzecznictwa sądów niemieckich członek rodziny nie musi być świadkiem wypadku.

W większości sytuacji sądy niemieckie nie przyznają takiego zadośćuczynienia. Jeśli jednak tak się zdarzy, to jego wysokość waha się od kilku tysięcy (tak wykazuje analiza orzeczeń $z$ lat 90.) do 80000 euro (po 20000 euro dla rodziców i dwójki rodzeństwa) przyznanych w 2006 r. za śmierć 11-letniego dziecka. Ponadto, według prawa niemieckiego, spadkobiercy zmarłego pasażera mają możliwość uzyskania zadośćuczynienia za tzw. pre-death pain and suffering.

Wysokość zadośćuczynienia za tzw. pre-death pain and suffering zależy od tego, jak długo trwało cierpienie, zanim dana osoba zmarła. Według Federalnego Trybunału Sprawiedliwości (Bundesgerichtshof - BGH) w razie wypadku, w którym bezpośrednio poszkodowany został poważnie ranny i zmarł kilka sekund po wypadku, zadośćuczynienie nie przysługuje. Ważne też jest to, czy zmarły miał świadomość przed śmiercią, że umrze. Analiza orzeczeń sądów niemieckich prowadzi do stwierdzenia, iż wysokość zadośćuczynienia wynosi od 500 (za kilka minut cierpienia) do 20000 euro (za 36 godzin cierpienia) ${ }^{40}$.

Według polskiego prawa brakuje podstaw do zasądzenia zadośćuczynienia za cierpienia psychiczne członka rodziny (bezpośrednio poszkodowanego). Rodziny zmarłych otrzymałyby zadośćuczynienie za ich własne cierpienia po stracie najbliższych na podstawie art. 446 § 4 Kodeksu cywilnego. Pasażer, który przeżył katastrofę, mógłby otrzymać zadośćuczynienie w razie uszkodzenia ciała lub rozstroju zdrowia (art. 445 k.c.) lub też w razie naruszenia jego dóbr osobistych (art. 448 k.c.) ${ }^{41}$.

40 Zob. U. von Jeinsen, A. Konert, op.cit.

41 Zob. zwłaszcza: M. Wałachowska, Zadośćuczynienie pieniężne za uszko- 
Ponadto należy zastanowić się nad tym, czy jeśli uszkodzenie fizyczne ciała nastąpi później, jako skutek urazu psychicznego (np. jeżeli wypadek powoduje szkodę niemajątkową, która $z$ kolei wywołuje niekorzystne objawy fizyczne - poronienie), to czy wówczas pasażer nie ma możliwości uzyskania odszkodowania. Według interpretacji większości sądów (zwłaszcza amerykańskich) nie ma takiej możliwości, gdyż takie uszkodzenie fizyczne byłoby spowodowane przez tzw. non-recoverable psychic injury ${ }^{42}$. Wówczas bowiem to nie „wypadek”, lecz cierpienie psychiczne powoduje „szkodę" w rozumieniu art. 17 obu konwencji.

W Polsce kwestia uzyskania zadośćuczynienia w razie późniejszego doznania uszkodzenia ciała powinna być rozstrzygana przez sądy w kontekście istnienia związku przyczynowego. W brytyjskiej Izbie Lordów lord Steyn stwierdził, że jeżeli wypadek powoduje szkodę niemajątkową, która $z$ kolei wywołuje niekorzystne objawy fizyczne, takie jak np. udar mózgu, to pasażer powinien otrzymać odszkodowanie ${ }^{43}$.

\section{Podsumowanie}

Artykuł 17 konwencji warszawskiej i konwencji montrealskiej przewiduje przesłanki odpowiedzialności przewoźnika lotniczego za szkody poniesione przez pasażerów. Nie precyzuje on jednak rodzajów szkody, które mogą być przedmiotem roszczenia. Powstała wobec tego wątpliwość, czy szkody niemajątkowe podlegają kompensacji. Analizując istniejące orzeczenia wydane na podstawie przepisów obu konwencji, należy zauważyć, że w większości krajów

dzenie ciała lub wywołanie rozstroju zdrowia $w$ prawie polskim, w: Zadośćuczynienie za uszkodzenie ciała lub uszczerbek na zdrowiu na tle innych systemów prawnych, red. A. Koch, T. Kwieciński, J. Pokrzywniak, „Wiadomości Ubezpieczeniowe" 2012, nr 2 specjalny; eadem, Ustalenie wysokości zadośćuczynienia pieniężnego $w$ razie uszkodzenia ciała lub wywołania rozstroju zdrowia: glosa do wyroku z dnia 14 lutego 2008 r. (II CSK 536/07), „Przegląd Sądowy” 2011, nr 4, s. 131 i n.

42 Zob. Ch. Thalin, op.cit., s. 51.

43 [2002] UKHL 7, [2002] 2 AC 628 (U.K. House of Lords 2002). 
zadośćuczynienie jest możliwe jedynie wówczas, gdy szkoda niemajątkowa jest spowodowana fizycznym uszkodzeniem ciała. Powstaje jednak pytanie, czy istnieje możliwość uzyskania zadośćuczynienia tylko za szkodę niemajątkową (tzw. purely psychic injury) oraz czy można uzyskać odszkodowanie, gdy ta „czysta” niemajątkowa szkoda spowodowała następnie uszkodzenie fizyczne ciała.

Jedynie system prawa włoskiego rozwiązał ten problem interpretacyjny, wprowadzając bezpośrednio możliwość uzyskania zadośćuczynienia poprzez odwołanie do zasad konstytucyjnych. Jednakże według sądów w większości krajów przedstawionych w niniejszym opracowaniu w systemie warszawsko-montrealskim istnieje możliwość uzyskania zadośćuczynienia - w razie wystąpienia uszkodzenia ciała, które spowodowało powstanie także szkody niemajątkowej. Jedynym rozsądnym wytłumaczeniem wąskiej interpretacji pojęcia szkody i zakresu jej kompensacji przez sądy krajowe jest uniknięcie nadmiernej liczby pozwów tylko za szkody niemajątkowe oraz trudności w udowodnieniu, że pasażer takiej szkody nie poniósł. Ponadto sądy często powoływały się na wykładnię historyczną, zastanawiając się, jaka była intencja twórców konwencji, a także - co należy rozumieć przez pojęcie lésion corporelle. Wydaje się, po ponad 90 latach obowiązywania konwencji warszawskiej, że kontekst historyczny powinien mieć mniejsze znaczenie niż kontekst funkcjonalny i celowościowy. Dochodzimy bowiem do następującej logiki. Jeżeli pasażer przeżył wypadek lotniczy, np. wyskoczył z płonącego samolotu na płycie lotniska, to nie należy mu się zadośćuczynienie, ale jeśli nie udało mu się opuścić samolotu, to jego rodzina otrzyma zadośćuczynienie za jego cierpienia psychiczne (jeśli pozwala na to właściwe prawo krajowe). Taka interpretacja przepisów konwencji prowadzi do sytuacji, w której sama śmierć jest gwarancją autentyczności szkód niemajątkowych, a fakt, że śmierć następuje po cierpieniu psychicznym (lub nawet nie ma związku $z$ takim cierpieniem), nie powinien być istotny ${ }^{44}$.

44 S.R. Pounian, M.W. Benett, Recovery for Psychic Injuries under Warsaw, Montreal Conventions, „New York Law Journal Online”, https://www.kreindler. com/articles/psychic-injuries-under-warsaw-montreal-conventions (dostęp: 13.07.2021 r.). 
Wyrok TSUE w sprawie Axel Walz $v$. Clickair SA stanowił przełom w interpretacji przepisów konwencji montrealskiej, uznano w nim bowiem za możliwe dochodzenie obu rodzajów szkody. Wprawdzie orzeczenia Trybunału mają charakter quasi-precedensów i sądy, wydając wyroki w podobnych sprawach, nie zmieniają wytyczonego już kierunku interpretacji, ale nie jest to równoznaczne $z$ wykluczeniem możliwości modyfikacji tego stanowiska. Ostatecznie więc decyzję w przedmiocie kompensacji szkody niemajątkowej doznanej podczas lotów międzynarodowych podejmie sąd orzekający w danej sprawie, w praktyce często biorąc pod uwagę właściwe prawo krajowe (prawo sądu orzekającego). Wobec tego sądy w Polsce, powołując się na wyrok TSUE w sprawie Axel Walz v. Clickair SA, będą stosować zasady wynikające $z$ Kodeksu cywilnego w celu precyzyjnego ustalenia możliwości i zakresu dochodzenia roszczeń z tytułu szkody niemajątkowej.

\section{STRESZCZENIE}

Zadośćuczynienie za szkodę niemajątkową w wypadkach lotniczych podczas podróży międzynarodowych

Odpowiedzialność cywilna przewoźnika lotniczego wobec pasażerów w transporcie międzynarodowym jest regulowana przez przepisy konwencji warszawskiej i montrealskiej. Żaden $z$ traktatów nie reguluje szczegółowo definicji i zakresu szkód. Jednakże stanowią one upoważnienie dla sądów do stosowania prawa krajowego w celu określenia, jakiego rodzaju szkody mogą być przedmiotem roszczenia i kto może domagać się ich naprawienia. Kwestia, czy przewoźnik lotniczy mógłby i powinien zostać pociągnięty do odpowiedzialności wobec pasażera za szkody niemajątkowe (krzywdy moralne), jest szeroko dyskutowana i stanowi przedmiot rozważań wielu sądów. Celem artykułu jest pokazanie możliwych sposobów interpretacji traktatów w różnych jurysdykcjach i określenie możliwości dochodzenia zadośćuczynienia za szkody niemajątkowe przez pasażerów lotniczych.

Słowa kluczowe: konwencja montrealska; konwencja warszawska; odpowiedzialność cywilna przewoźnika lotniczego; zadośćuczynienie za krzywdę moralną; odszkodowanie za wypadek lotniczy 


\section{SUMMARY}

Compensation for non-pecuniary damage in air accidents while traveling internationally

The civil liability of airlines to passengers on international transportation is governed by the Warsaw and Montreal Conventions. None of the treaties contain substantive law on the issue of damages, functioning instead as a "pass-through" that authorizes courts to apply domestic law to specify what harms are cognizable and by whom. Whether an air carrier could and should be held liable to a passenger for emotional trauma alone is wildly discussed and has been the subject of investigation by many courts. The goal of the article is to show the possible ways of interpretation of the treaties in different jurisdictions.

Keywords: Montreal Convention; Warsaw Convention; civil liability of an air carrier; compensation for moral damages; air accident compensation

\section{BIBLIOGRAFIA}

Boulee J.P., Recovery for mental injuries that are accompanied by physical injuries under article 17 of the Warsaw Convention: the progeny of Eastern airlines, inc. V. Floyd, „Georgia Journal of International and Comparative Law" 1994, Vol. 24.

Dempsey P.S., Accidents \& Injuries in International Air Law: The Clash of the Titans, „Annals of Air and Space Law” 2009, Vol. 34.

Fromm L.M., Eastern airlines v. Floyd: Airline passengers denied recovery for emotional distress under the Warsaw Convention, „Akron Law Review" 1991, Vol. 25.

Holland M.J., The Puzzle of Defining "Bodily Injury" under the Warsaw Convention, „Defense Counsel Journal” 2003, Vol. 70.

Immel J.J., The Montreal Convention and Recovery for Free-Standing Emotional Distress under Article 17, „Issues in Aviation Law and Policy” 2013, Vol. 13, No. 1.

Jeinsen U. von, Konert A., Are non pecuniary damages recoverable in Europe? A Comparative Analysis, „Annals of Air and Space Law” 2009, Vol. 24. 
Kirpalani M.M., Hasiotis Ch., Defense of Psychological Injury Claims: An Update on Post-Traumatic Stress Disorder, „Journal of Air Law \& Commerce", SMU, 1996, Vol. 62.

Konert A., Odpowiedzialność cywilna przewoźnika lotniczego, Warszawa 2010.

Konert A., Prawotwórcza moc TSUE - clara non sunt interpretanda?, w: Internacjonalizacja i europeizacja prawa lotniczego. Księga pamiatkowa na cześć Prof. dr. hab. Marka Żylicza, red. A. Konert, Warszawa 2015.

Konert A., Zadośćuczynienie za szkodę niemajątkowa spowodowana utrata bagażu - glosa do wyroku TS (trzecia izba) z 6.05.2010 r. w sprawie C-63/09 Axel Walz v. Clickair S.A., „Europejski Przegląd Sądowy” 2011 , nr 10.

Konert A., Zakres zastosowania Rozporzadzenia 261/2004 - glosa do wyroku TS (czwarta izba) z dnia 10 lipca 2008 r. w sprawie C-173/07 Emirates Airlines Direktion für Deutschland przeciwko Dietherowi Schenkelowi, „Europejski Przegląd Sądowy” 2014, nr 4.

Krukow P., Lipczyński A., Zespół stresu pourazowego - charakterystyka psychologiczna i neuropsychologiczna, Psychiatria.pl, 21 lipca 2007 r., https://www.psychiatria.pl/artykul/zespol-stresu-pourazowego-charakterystyka-psychologiczna-i-neuropsychologiczna/3694/3.

Kull I., w: European Tort Law 2005, eds. H. Koziol, B.C. Steininger, WienNew York 2006.

Pounian S.R., Benett M.W., Recovery for Psychic Injuries under Warsaw, Montreal Conventions, „New York Law Journal Online”, https://www. kreindler.com/articles/psychic-injuries-under-warsaw-montreal-conventions.

Rees J., Getting from Warsaw to Gerona: a tour operator's liability, „International Travel Law Journal” 2004, Vol. 1.

Rivers jr R.J., Torts - International infliction of emotional distress, „Suffolk Transnational Law Journal” 1990, No. 14.

Schmidt J., Compensability for PTSD under the Montreal Convention: Psychiatric Injury as a Bodily Injury, „Journal Psychiatry, Psychology and Law" 2015, Vol. 22, Issue 5.

Thalin Ch., The Air Carrier's Liability for Passenger Damages - Article 17 of the Warsaw System and the new Montreal Convention, Master thesis 2002. 
$136 \mid$ Anna Konert

Wałachowska M., Ustalenie wysokości zadośćuczynienia pieniężnego $w$ razie uszkodzenia ciała lub wywołania rozstroju zdrowia: glosa do wyroku z dnia 14 lutego 2008 r. (II CSK 536/07), „Przegląd Sądowy” 2011, nr 4.

Wałachowska M., Zadośćuczynienie pieniężne za uszkodzenie ciała lub wywołanie rozstroju zdrowia $w$ prawie polskim, w: Zadośćuczynienie za uszkodzenie ciała lub uszczerbek na zdrowiu na tle innych systemów prawnych, red. A. Koch, T. Kwieciński, J. Pokrzywniak, „Wiadomości Ubezpieczeniowe" 2012, nr 2 specjalny. 